\title{
Emissive sources agricultural: evolutionary trends in the Mediterranean basin. Impact sustainable development
}

\author{
[Allegra V., Muratore F., Bracco S.]
}

\begin{abstract}
Climate change is current topic of great interest on the social level and its impact on the agri-food, and on food security. The international debate on the topic is very bright for the repercussions on the future human survival on our planet because of the consequent gradual reduction of agricultural production and livestock breeding. The prevailing relative importance of environment polluting emissions is harged to the agri-food sector (25-30\% of the total). What actually expresses an imperfection informative by separating agriculture from related activities industry and services, can emerge the accused sector of concrete threat climate risk. The breakdown by sector of economic activity appears important to address environmental risks with specific means by sector suitable for providing sustainable food systems. This paper aims to analyze a historical trend in the medium-term impact of agriculture on the global environment, for the main polluting types drawn from the international statistical source FAO. This study points to countries of the Mediterranean basin, here in fact one of the ecosystems most affected by of global warming. The importance of such events becomes even more significant taking into account the forecasts of the Intergovernmental Panel on Climate Chang (IPCC) regarding to the increase of population in the countries bordering the Mediterranean (525 million people in 2020).
\end{abstract}

Keywords-GHG emission, Agriculture, Food sustainable, Resilience, Mediterranean Area.

\section{Introduction}

The emergency of climate change is one of the most alarming issues of the last years. The causes of the warming of the atmosphere can be attributed to the so-called greenhouse gases that limit the radiations emitted by the Earth's surface. This phenomenon makes sure that the impacts of climate change can vary in a significant way depending on the environmental, political, social and economic context in which they are realized and, of course, depending on the adaptability of the different territorial systems [1].

Allegra Valeria

University of Catania, Department Di3A

Italy

Muratore Francesco

University of Catania, Department Di3A

Italy

Bracco Salvatore

University of Catania, Department Di3A

Italy
In fact, the effects of the impacts, which have evolved as an outcome of the variation of climate change, have an influence on our health and food safety, also in relation to the quality and availability of the territory's resources. The range of the main territories from which greenhouse gases are emitted (especially some specific countries) includes the Mediterranean Basin [2], [3]. It concerns with an environmental scenario in which the space-time variable determines the evolution process of climate change because of the accumulation of gases in the atmosphere (i.e. carbon dioxide, methane, nitrogen oxide), which are often missing among its natural components (i.e. fluorinated gases of industrial origins). The most known gas with which man has contributed in altering the natural composition of the atmosphere is carbon dioxide $\left(\mathrm{CO}_{2}\right)$, which more than other gases is responsible for the increase of our planet's temperature; among the major causes, we find the deforestation which determines a minor absorption of this gas. Among the main gases that are responsible for the global warming we find methane and nitrous oxide. Agriculture has a significant impact on the atmosphere since it is a source of emission of the two already mentioned gases $\left(\mathrm{CH}_{4}\right.$ and $\left.\mathrm{N}_{2} \mathrm{O}\right)$, which have a higher warming potential than $\mathrm{CO}_{2}$ [4], [5]. Agriculture is meant as a primary activity and not as agribusiness, and its responsibility of gas emission in the atmosphere [6], [7], unlike the global emission related, is interpreted at the same moment.

\section{Methodology}

In order to underline the dynamic and the quantities of greenhouse gases' emissions in the atmosphere, some information have been elaborated and published by World Data Bank-World Development Indicators (WB) [8]. The greenhouses gases considered of agriculture production for countries Mediterranean Basin, they are detected by FAOstat. The WB and FAOstat [9] found out the amount of methane $\left(\mathrm{CH}_{4}\right)$ and nitrous oxide $\left(\mathrm{N}_{2} \mathrm{O}\right)$ in thousands of tons of $\mathrm{CO}_{2}$ equivalent. The equivalence of greenhouse gases expressed in $\mathrm{CO}_{2}$ indicates the global warming potential (GWP), or rather the greenhouse effect potential. The potential of greenhouse gases in terms of $\mathrm{CO}_{2}$ equivalent, equal to 1, is the following: methane $\left(\mathrm{CH}_{4}\right) 21$ times and nitrous oxide $\left(\mathrm{N}_{2} \mathrm{O}\right) 310$ times. The analysis period covers a time span of twenty years, especially from the Kyoto Protocol - an international treaty to contrast the global warming, which was adopted in 1997 during the Conference of the Parties in Kyoto (COP3) - to the 
Proc. of the Fourth International Conference on Advances in Social Science, Management and Human Behaviour - SMHB 2016. Copyright ( $)$ Institute of Research Engineers and Doctors. All rights reserved.

ISBN: 978-1-63248-116-0 doi: 10.15224/ 978-1-63248-116-0-66

preparatory years of Climate Change Conference (COP21) held in Paris in 2015.

It been the object of determining the environmental social hazard index space-time. The aim has been determined the statistical derivation relationship between GHG emissions and population [10]. This considering that the population is a general assumption of GHG emissions intensity. The derivation relationship is calculated by dividing the total greenhouse gas emission phenomenon and the phenomenon of greenhouse gases the agriculture compared the population. The environmental hazard index space-time it was determined with reference to the most populated countries of the Mediterranean basin. Has been also the focus of solve the hazard index agro-forestry land use space-time [11].

\section{Results}

In the period that goes from 1995 to 2013, the total emission of greenhouse gases went from 38.030,6 mln tons to $52.763,4 \mathrm{mln}(+39 \%)$. During the same period, the methane emission coming from agriculture has increased to a much lesser extent, from 3.080,3 $\mathrm{mln}$ tons to $3.367,2 \mathrm{mln} \mathrm{(+9 \% ),}$ nitrous oxide $\left(\mathrm{N}_{2} \mathrm{O}\right)$ from $1.743,3$ to $2.118,9 \mathrm{mln}(22 \%)$ (Figure 1).

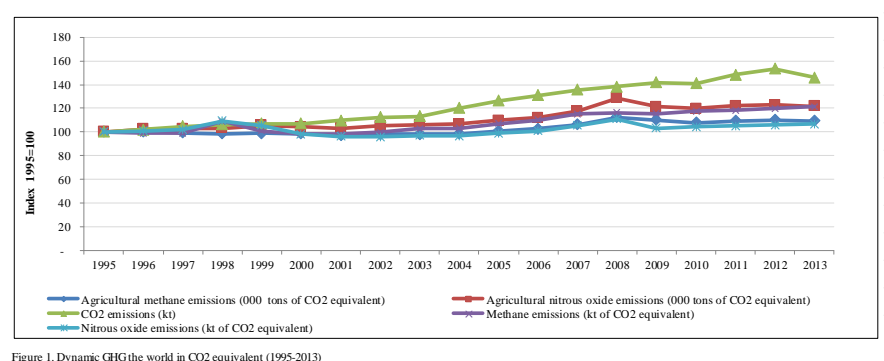

Figne

Then again, agriculture products are quantitatively and qualitatively strongly influenced by climate change, with direct effects different for every specie, and indirect effects different because of the crop management, which can be extensive or intensive. However the agriculture, including livestock, significantly contributes to the increase of greenhouse gases. The total emissions in the Mediterranean Basin area (Figure 2) increased from $2.196 .7 \mathrm{mln}$ tons to 2,752.2 million tons. In agriculture there was an increase of $\mathrm{CH}_{4}$, from $132.8 \mathrm{mln}$ tons to $134,7 \mathrm{mln}(+1 \%)$.

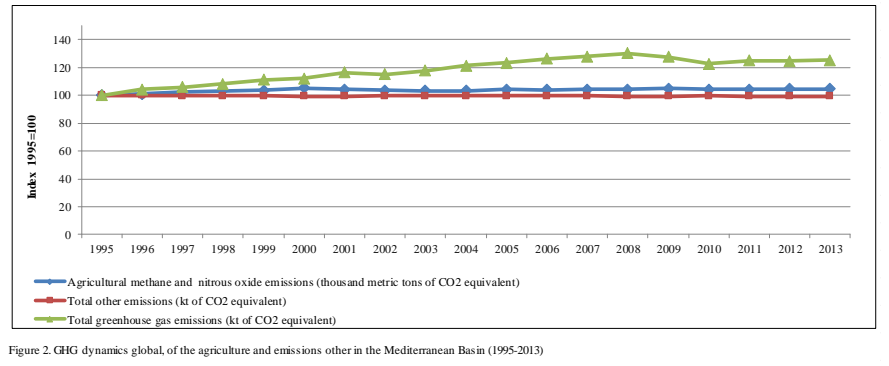

Finally, an analysis of each country of the Mediterranean Basin has shown that the emissions of methane and nitrous oxide can be attributed to France, which that for these greenhouse gases is perhaps the most polluting country of the Mediterranean area. For what concerns the $\mathrm{CO}_{2}$ emissions per person, Italy is the most polluting country. In relative terms, Mediterranean Basin between 1997 and 2013 (Table 1), the global greenhouse gas emissions, increased by more than $18 \%$; while the agriculture of $7 \%$.

TABLE I. GHG GLOBAL AND OF THE AGRICULTURE IN THE MEDITERRANEAN BASIN

\begin{tabular}{|c|c|c|c|c|c|c|}
\hline \multirow{2}{*}{ Countriers } & \multicolumn{3}{|c|}{ Global (*) } & \multicolumn{3}{|c|}{ Agricultural total $(* *)$} \\
\hline & 2005/1997 & $2013 / 2005$ & 2013/1997 & $2005 / 1997$ & $2013 / 2005$ & 2013/1997 \\
\hline South shore & 26,74 & 26,47 & 60,28 & 24,64 & 6,82 & 33,14 \\
\hline Algeria & 13,03 & 26,19 & 42,63 & 17,63 & 31,94 & 55,20 \\
\hline Cyprus & 25,88 & $-14,83$ & 7,21 & 4,79 & $-12,90$ & $-8,73$ \\
\hline Egypt, Arab Republic & 40,27 & 32,30 & 85,57 & 30,63 & 0,09 & 30,75 \\
\hline Morocco & 56,83 & 21,89 & 91,16 & 17,76 & 11,71 & 31,56 \\
\hline Tunisia & 24,78 & 22,11 & 52,37 & 15,33 & $-1,44$ & 13,68 \\
\hline Libya & 1,96 & 19,78 & 22,12 & 36,53 & 0,92 & 37,78 \\
\hline North shore & 12,78 & $-6,05$ & 5,95 & $-5,91$ & $-4,37$ & $-10,02$ \\
\hline France & $-2,08$ & $-10,97$ & $-12,82$ & $-8,02$ & $-4,24$ & $-11,92$ \\
\hline Italy & 10,93 & $-14,24$ & $-1,74$ & $-9,17$ & $-3,21$ & $-12,09$ \\
\hline Malta & 13,54 & $-36,39$ & $-27,78$ & $-7,17$ & $-5,41$ & $-12,19$ \\
\hline Spain & 35,93 & $-17,30$ & 12,42 & 2,39 & $-7,26$ & $-5,04$ \\
\hline Greece & 15,40 & $-14,86$ & $-4,87$ & $-9,04$ & 3,51 & $-5,85$ \\
\hline East shore & 18,64 & 27,48 & 51,24 & $-2,70$ & 16,73 & 13,58 \\
\hline Turchia & 19,96 & 33,63 & 60,30 & $-8,12$ & 24,97 & 14,82 \\
\hline Other & 37,66 & 10,60 & 52,25 & 0,27 & $-2,59$ & $-2,33$ \\
\hline Mediterranean basin & 16,24 & 1,67 & 18,18 & 0,41 & 6,62 & 7,06 \\
\hline World & 16,16 & 18,21 & 37,31 & 6,13 & 6,72 & 13,25 \\
\hline
\end{tabular}

The largest increase in emissions from agriculture will have in the east shore; especially in the Turkey. Between North and South is Different. The emission is increasing on the South shore, especially evolutionary positions among the countries, also ups and downs. On the North shore the tendency is to the reduction. Although the Kyoto Protocol has not been put into operation, on reducing greenhouse gases (GHG emissions) by man in the North shore have affected the environmental policies of the European Union: in fact, the reduction is apparent in every country of the Mediterranean Member States, especially in agriculture. Also important the economic policies aimed at reducing production (especially livestock) and the restraint of the use of chemicals in the soil and on the plants responsible for food insecurity. Finally, comparing GHG emissions global and agriculture to the population of the most populous countries of the Mediterranean Basin (Table II), it derives a scenario on the evolutionary potential of emissions, as well as verifying the differences in this regard between different countries.

\begin{tabular}{|c|c|c|c|c|c|c|c|c|}
\hline \multirow{2}{*}{ Phenomenon } & \multicolumn{2}{|c|}{ Italy } & \multicolumn{2}{|c|}{ France } & \multicolumn{2}{|c|}{ Turkey } & \multicolumn{2}{|c|}{ Egypt, Arab Republic } \\
\hline & 2013 & 2005 & 2013 & 2005 & 2013 & 2005 & 2013 & 2005 \\
\hline Population (a) & 61,7 & 58,1 & 66,3 & 60,7 & 81,6 & 69,7 & 86,9 & 77,5 \\
\hline Agricultural (GHG) (b) & 0,030 & 0,031 & 0,072 & 0,072 & 0,043 & 0,035 & 0,031 & 0,031 \\
\hline GHGemissions (c) & 0,483 & 0,563 & 0,499 & 0,561 & 0,446 & 0,334 & 0,223 & 0,230 \\
\hline b x 100/a & 0,049 & 0,054 & 0,109 & 0,119 & 0,053 & 0,050 & 0,036 & 0,040 \\
\hline \multirow[t]{6}{*}{$\mathrm{c} \times 100 / \mathrm{a}$} & 0,783 & 0,969 & 0,753 & 0,925 & 0,546 & 0,479 & 0,257 & 0,297 \\
\hline & \multicolumn{8}{|c|}{ (a) Million people; (b) and (c) million $\mathrm{CO} 2$ equivalent } \\
\hline & \multirow{2}{*}{\multicolumn{8}{|c|}{$\begin{array}{l}\text { Our elaboration of statistics data taken: } \\
\text { (a) Indexmundi }\end{array}$}} \\
\hline & & & & & & & & \\
\hline & \multicolumn{8}{|c|}{ (b) Faostat Emissions database Agriculture } \\
\hline & \multicolumn{8}{|c|}{ (c) World Bank Open Data } \\
\hline
\end{tabular}


Proc. of the Fourth International Conference on Advances in Social Science, Management and Human Behaviour - SMHB 2016. Copyright ( $)$ Institute of Research Engineers and Doctors. All rights reserved.

ISBN: 978-1-63248-116-0 doi: 10.15224/ 978-1-63248-116-0-66

The table III shows the weight of GHG emissions on the surface area dedicated to forests and agricultural activities in the most populous countries previously considered. In the decade analyzed, in observation object countries, there were no remarkable changes of the effects of GHG on the UAA. Indeed, Egypt manifested a more marked reduction of the index in question in the face of an increase in the UAA. One might attribute to this country a higher recent sensitivity to environmental sustainability. For Turkey, the time values of the index derivation in question confirm a growing trend of environmental impacts. As for France and Italy confirmed tendency to support environmental sustainability and consequently the more guarantee agriculture products.

\begin{tabular}{|c|c|c|c|c|c|c|c|c|}
\hline \multirow{2}{*}{ Phenomenon } & \multicolumn{2}{|c|}{ Italy } & \multicolumn{2}{|c|}{ France } & \multicolumn{2}{|c|}{ Turkey } & \multicolumn{2}{|c|}{ Egypt, Arab Republic } \\
\hline & 2013 & $2005^{(\mathrm{d})}$ & 2013 & $2005^{(\mathrm{d})}$ & 2013 & $2005^{(\mathrm{d})}$ & 2013 & $2005^{(\mathrm{d})}$ \\
\hline $\mathrm{UAA}^{(\mathrm{a})}$ & 0,220 & 0,247 & 0,527 & 0,529 & 0,506 & 0,507 & 0,038 & 0,036 \\
\hline Agricultural (GHG) ${ }^{(b)}$ & 0,030 & 0,031 & 0,072 & 0,072 & 0,043 & 0,035 & 0,031 & 0,031 \\
\hline GHGemissions $^{(c)}$ & 0,483 & 0,563 & 0,499 & 0,561 & 0,446 & 0,334 & 0,223 & 0,230 \\
\hline $\mathrm{b} / \mathrm{a}$ & 0,137 & 0,127 & 0,137 & 0,136 & 0,085 & 0,069 & 0,817 & 0,863 \\
\hline \multirow[t]{7}{*}{$\mathrm{c} / \mathrm{a}$} & 2,195 & 2,279 & 0,947 & 1,060 & 0,881 & 0,659 & 5,868 & 6,389 \\
\hline & & & \multicolumn{6}{|c|}{ (a) Million utilised agricultural area; (b) and (c) million $\mathrm{CO} 2$ equivalent } \\
\hline & & & & & \multirow{2}{*}{\multicolumn{4}{|c|}{$\begin{array}{l}\text { Our elaboration of statistics data taken: } \\
\text { (a) Indexmundi }\end{array}$}} \\
\hline & & & & & & & & \\
\hline & & & & & \multicolumn{4}{|c|}{ (b) Faostat Emissions database Agriculture } \\
\hline & & & & & \multicolumn{4}{|c|}{ (c) World Bank Open Data } \\
\hline & & & & & \multicolumn{4}{|c|}{ (d) www.ptl.regione-sicilia.it } \\
\hline
\end{tabular}

With the analysis of date statistic is therefore confirmed the general trend of agriculture to take on less responsibility in the emission of greenhouse gases. The question connects on security aspects in agriculture. It is, however, the connection identify, ie if security is seen in relation to the production and / or supply chain of food (food security), or in relation to the health (food safety). The two terms, therefore, involve different security phenomena, even though they are complementary; in fact, they are cause and effect of one another. Although the participation of greenhouse gas emissions from agriculture to GHG emissions becomes gradually less influential, globally the issue of food security prevails on the subject of food safety. The negative effects of climate change and related phenomena is connected food insecurity or malnutrition and extreme poverty; problem of food shortages. The establishment of stocks and food and emergency plans are actions aimed at ensure safer supplies for families. To achieve all this, agriculture devote attention; taking into account that in addition to production also the necessary service activities (transport, communications, etc.), contribute to the emission of greenhouse gases; determining of climate change. Therefore, agriculture could be considered one of the main determinants of the environmental pollution, especially in specific geographical areas of the Planet. Therefore, agriculture, as food security, becomes a participant in greenhouse gas emissions, especially with the activities that revolve around impact globalization which has changed profoundly the goods movement. Instead, agriculture, as food safety, suffers the negative effects of climate change, being in this case to be interested in health and hygiene the food sphere. Also in this case it does not escape the agriculture by the being considered among the causes of environmental pollution with the production of scraps and waste along the whole supply chain. Their recycling would contribute to emission reductions. Important the global message FAO for World Food Day 2016: "Climate is changing. Food and agriculture must too". "Growing food in a sustainable way means adopting practices that produce more with less in the same area of land and use natural resources wisely. It also means reducing food losses before the final product or retail stage through a number of initiatives including better harvesting, storage, packing, transport, infrastructure, market mechanisms, as well as institutional and legal frameworks" [12]. However, it is quite complicated define the full implications of greenhouse gas emissions on the various aspects of security in the agricultural sector; especially when it the phenomenon is also related to the characteristics of the regional climate and to the variations. Climatic change Mediterranean Basin it is area particularly exposed; very rainy North shore, while the South shore is rather dry. "Instability of climatic" and "climate change" GHG emissions in the atmosphere together increase the risk of adverse events in agriculture due to the alteration of the: precipitation patterns; thermal balance; evaporation; soil water content and quality of groundwater and surface waters.

Quality climate phenomena they act directly and indirectly on the agriculture, particularly on product safety. Focusing attention on water resources used for consumption human, groundwater represent the largest source of supply in arid and semi-arid areas and an important source of water demand dynamics (food security); while useful surface waters for agricultural production are directly subjected to dangerous pollutants (chemical, physical and biological agents) damaging to the products, therefore men (food safety). Climate change directly attached to the question of nutritional needs and of the agricultural productivity territorially. The demographic pressure the South shore of the Mediterranean Basin puts agriculture as the fundamental tool for sustainable development and poverty reduction. Agriculture the South shore therefore required to cope situations of undernourishment and malnutrition; in this context, therefore, in addressing problems of food security the evidence appears to be more realistic if the interrelationship of factors are considered as "food and nutrition security"[13].

Anyhow, in some of territorial realities in the Mediterranean area, agricultural productivity and profitability of agriculture are increasing; the growth of its greenhouse gas emissions imposes to undertake a model sustainability for the increase productivity consequent [14]. Naturally, also apply countries of the North shore, the sustainable modes of production associated with climate change taking place and in future; however here the strategic actions are also connected in a more complex matter "climate for health." Climate change affect the spread of diseases and contamination of agricultural products and foodstuffs; ways to fight and control may become determinants random adverse of the health. The change of food lifestyles, ie with a high service content (time saving), accentuates the risks to health. This implies environmental sustainable interventions in upstream sectors (water, soil, pesticides, fertilizers) and downstream (processing, storage, transport, waste) agriculture, which has not always closely related to health. Whatever the interventions to mitigate GHG emissions, to be taken in both the North shore and in the South shore, it is important that the 
Proc. of the Fourth International Conference on Advances in Social Science, Management and Human Behaviour - SMHB 2016. Copyright $(\odot$ Institute of Research Engineers and Doctors. All rights reserved.

ISBN: 978-1-63248-116-0 doi: 10.15224/ 978-1-63248-116-0-66

system continues to perform its functions for the nutrition and well-being of the population (resilience).

In the face of countless scientific aspects of climate change impacts on agriculture, we have placed emphasis on the safety of food products observing the influence of human activities (food safety) compared to natural climate (food security). The topics represent a first attempt to demonstrate that security in the agricultural sector can identify a unique relationship between human activities or between climatic variations. The possibility of separating into precise causal sequences determinants anthropogenic from natural ones can be instrumental in taking forward the knowledge to identify the most effective measures to mitigate and adapt to the effects of climate changes underway.

\section{Conclusions}

This analysis leads to ponder about the quality of agriculture products and the food security, which have been questioned because of climate change. There are some examples, including the alterations applied to sugar and starch's contents, but also nitrogen and phenolic compounds, plant-pathogen or fruit-pathogen interactions; and the spread of various pathogens, which appeared in the Mediterranean countries causing serious damages to agriculture. Just to give a few examples, we can mention the Xylella "Fastidiosa", a bacteria that destroyed a huge amount of olive groves in Puglia, Italy; then again, the citrus' tristeza (sadness) caused by Citrus tristeza virus; etc. It is clear that the invasion of pathogens is not exclusively attributed to the atmospheric warming. however, that's what the detected signals make people think. For example, the warming of the seas favored the arrival and acclimatization of some predators of Mediterranean fishes. All this facts make us consider that some of the adjustments' effects affect the plant and animal world. Various researchers and scholars are considering the consequences for food safety and quality. The intervention of public authorities by taking focused actions could play a key role in management decisions related to environmental issues. In this direction, the climate change Conference in Paris with the aim to "accelerate the reduction of greenhouse gas emissions." In the same direction, we find the Climate Change Conference held in Paris, the aim of which is "to accelerate the reduction of the emission of greenhouse gases". The Agreement signed by 195 countries (Cop21) has recently (October 4, 2016) been ratified by the European Union; with the European vote, the critical threshold of the responsible countries is exceeded by the $55 \%$ of global emissions (China and the US contribute together with 38\%), therefore, after the UN communication, the Agreement shall definitively enter into force. It is a 'historic vote'; Ban Kimoon (General UN Secretary) said that the agreement "would trigger the transition towards a low-carbon and climateresilient economic, we need to keep the rising of the temperature below 2 degrees". Whereas the President of the "Commission of the Environment, Public Health and Food Safety", Giovanni La Via, stated: "with the ratification of the agreement on Paris' climate, there's a hope for a better world. We must leave a more stable, more prosperous and cleaner planet to next generations. Today we're making a step towards that direction: today we can". The preparations for the entry into force of the Paris Agreement will soon take place in Marrakech with the Conference of the Parties (COP 22) of the UNFCCC (United Nations Framework Convention on Climate Change). Noteworthy for its effects on the agri-food system, another recent agreement of major importance on the reduction of GHG emissions; Kigali (Rwanda), 200 countries have adopted a plan to phase out the production and consumption of refrigerant gases (hydrofluorocarbons -HFCs) extremely harmful to the environment (super greenhouse gases). The importance of such events becomes even more significant taking into account the forecasts of the Intergovernmental Panel on Climate Chang (IPCC) regarding to the increase of population in the countries bordering the Mediterranean (525 million people in 2020).

\section{References}

[1] X. Zhu-Barker, M. Burger, W.R. Horwath and P.G. Green, "Direct green waste land application: How to reduce its impacts on greenhouse gas and volatile organic compound emissions?", Waste Management, vol. 52, pp. 318-325, June 2016.

[2] A.S. Zarbà, G. Di Vita, and V. Allegra, "Strategy development for Mediterranean pot plants: A stakeholder analysis", Quality - Access to Success, vol. 14, Issue SUPPL. 1, pp. 52-58, March 2013.

[3] S. Bosco, N. Nassi o Di Nasso, N. Roncucci, M. Mazzoncini, and E. Bonari, "Environmental performances of giant reed (Arundo donax L.) cultivated in fertile and marginal lands: A case study in the Mediterranean”, European Journal of Agronomy, vol. 78, August 2016, pp. 20-31, August 2016.

[4] R. Solazzo, M. Donati, L. Tomasi and F. Arfini, "How effective is greening policy in reducing GHG emissions from agriculture? Evidence from Italy", Science of the Total Environment. vol. 573, pp. 11151124, 2016.

[5] V. Allegra, S. Bracco and A.S Zarbà, "Environmental sustainability of agri-food smes. The case of dairy enterprises", Quality - Access to Success, vol. 16, pp. 172-179, January 2015.

[6] G. Guardia, A. Tellez-Rio, S. García-Marco, D. Martin-Lammerding, J.L. Tenorio, M.T. Ibáñez, and A. Vallejo, "Effect of tillage and crop (cereal versus legume) on greenhouse gas emissions and Global Warming Potential in a non-irrigated Mediterranean field", Agriculture, Ecosystems and Environment, vol. 221, pp. 187-197, April 2016.

[7] G. Guardia, D. Abalos, S. García-Marco, M. Quemada, M. AlonsoAyuso, L.M. Cárdenas, E.R. Dixon and A. Vallejo, "Effect of cover crops on greenhouse gas emissions in an irrigated field under integrated soil fertility management", Biogeosciences, vol. 13, Issue 18, pp. 52455257, September 2016

[8] data.worldbank.org

[9] faostat.fao.org

[10] www.indexmundi.com

[11] www.ptl.regione-sicilia.it

[12] www. fao.org/world-food-day/2016

[13] D. Romano, "La sicurezza alimentare da qui al 2050", Agriregionieuropa, n. 40, 2015.

[14] R. Misso, "L'uomo, il clima, l'agricoltura", FrancoAngeli. 2010.

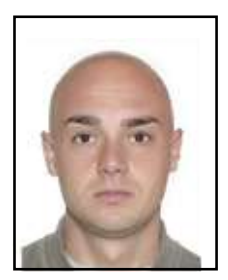

The theme is of global significance as evidenced by the negotiations on GHG emissions: Conference in Paris with the aim to "accelerate the reduction of greenhouse gas emissions" and in Kigali (Rwanda) global deal to limit use of HFCs (hydrofluorocarbons). The impacts on agriculture in greenhouse gas emissions have a double meaning: "food and nutrition security" and ' 